\title{
Check and Balance Power in Land Acquisition: A Case Study of Vietnam
}

\author{
Pham Thanh Nga, \& Assoc. Prof. Dr. Doan Hong Nhung \\ School of Law, Vietnam National University, Hanoi, Vietnam \\ DOI - http://doi.org/10.37502/IJSMR.2021.4508
}

\begin{abstract}
Managing land is a complicated issue not only in Vietnam but also many countries around the world. In recent years, there have been many cases related to violations of land acquisition in Vietnam. This situation makes people not trust in the leadership of the Communist Party and the State as well as reduces the confidence of investors and enterprises when conducting land lease activities for business development in Vietnam. One of the reasons for illegal land acquisition is that the state's control over power is still inadequate. In this paper, the author will analysis detail the controlling power in land acquisition in Vietnam and recommend some solution to solve the related problems.
\end{abstract}

Keywords: Check and Balance; Power of State; Governing; Land Acquisition; Vietnam.

\section{Introduction}

State power, on the one hand, is essential for maintaining social order; on the other hand, there is always a tendency to be abused by holders. Therefore, state power needs to be controlled. This control can be explained for the following reasons:

i. First of all, control over state power comes from the origin and nature of the socialist rule of law state as "All state power belongs to the people". State power is not the self-made power of the State but it is the power of the people, authorized by the people. The people do not directly exercise their power but authorize the State to do it on their behalf. Therefore, inevitably arises a legitimate and natural requirement to control state power. On the other hand, when delegating to the State, state power often moves in the direction of self-negation, becoming the opposite of itself at the beginning (the word of the people is the majority changing to the few of a certain number of people). Group or of a person). Therefore, controlling state power is an objective demand from the principal - the people to the authorized person - the State. Moreover, state power is not a quantity that can be accurately weighed, measured, and counted, so that it can be specifically delegated. That requires even more control of state power to limit abuse of power and limited effective exercise of state power. Stemming from the above objective requirements, state power is often quantified and divided into legislative, executive and judicial powers. 
ii. State power is assigned to a group of people to hold, so it is easy to be manipulated and abused by individuals. In such circumstances, civil servants are often easily corrupted, leading to abuse and use of public power to carry out private work for personal gain.

iii. State power is the general will of society but is vested in a small number of people with limited powers of execution. It's hard for people not to make mistakes. However, due to the nature of state power, if this mistake occurs, the whole society will be subject to the consequences. Therefore, to minimize such mistakes, state power needs to be brought under control.

iv. The state is the subject of a monopoly of legal coercion. State power is often used to coerce and remove obstacles and behaviors that hinder the realization of the common interests of society. Then, if this power is used properly, it will bring order and development to society; on the contrary, if it is abused, there will be consequences for society. Reality shows that coercion and state intervention are not always correct and effective. Therefore, state power needs to be adjusted in a timely manner, regularly and strictly controlled.

v. In relation to state power, an objective fact often happens that citizens are not equal to the State in information. This right, together with information inequalities between the people and the State, creates opportunities for public officials to exercise their own interests or those of their allies, to the detriment of the common good. The possibilities for profit and corruption are enormous. Therefore, the control of state power is essential to protect the interests of the state and the people.

Controlling power in building a socialist rule of law state in Vietnam also stems from the characteristics of Vietnam led by a single Party. The leadership of the Communist Party of Vietnam over the State and society is a historical necessity. That inevitably requires the control of power in land acquisition among the subjects constituting the political system in Vietnam. Control of the people, the supreme subject of state power over state power. Controlling state power within the organization and operation of the state apparatus between legislative, executive and judicial powers, between central state power and local state power.

\section{Literature review}

\section{Some Concepts related to State power control}

The legal mechanism controlling state power is a collection of legal institutions and institutions that are closely related, operating in accordance with the law to prevent and eliminate risks and behaviors violating the law by subjects exercising state power, ensuring state power to operate according to the Constitution and law, for right purposes and effectively. Legal institution is the sum total of legal norms, closely related and unified, stipulating principles, order, procedures, content and legal consequences of controlling state power expressed in legal documents. The institutions controlling state power include agencies in the state apparatus such as the National Assembly, the President, the Government, the Prime Minister, the People's Court, the People's Procuracy, the state of auditor Agency, the National Election Council, the People's Councils and People's Committees at all levels; and external institutions such as: Communist Party of Vietnam, 
Vietnam Fatherland Front, Trade Union, Farmers' Union, Youth Union, Women's Union, Veterans Association, Social and professional organizations career, etc.

Legislative power is the right to represent the people to express the general will of the country. Representatives are elected by popular vote to form a body called the National Assembly. The basic attribute, throughout all activities of this right, is to represent the people, to ensure that the common will of the people is reflected in the laws of which it is the only body authorized by the people to vote. Passing laws is the legislative power. Besides, the National Assembly is the supreme supervisor on behalf of the people of all State activities, especially the exercise of executive power (the Government). This is a form of state power control within the state apparatus to help the executive and judicial agencies do the right thing, fulfill their assigned tasks and powers, and limit the abuse of power or misusing authority.

Executive power is the power to organize the implementation of the general will of the country, which is assumed by the Government. The basic attribute, throughout all activities of this right, is state management (or rule) which is essentially the organization of law enforcement to ensure security, safety and social development. Without a government that manages the state effectively and intelligently, it is impossible to have a prosperous and stable state in both economic and social terms. Exercising this right requires the Government and its members to be quick, decisive, and unified. At the same time, regular inspection and inspection is required - a form of power control within the executive apparatus.

Judicial power is the right to adjudicate, assigned by the people to courts and judicial agencies. Independence and only obeying the law is the most transparent and highest principle in the organization to exercise this right. All individuals, agencies and organizations are not allowed to interfere in the adjudication activities of the Court. This is essentially the right to protect the common will of the nation by adjudicating violations of the Constitution and laws by citizens and state agencies. Therefore, protecting the law, justice and freedom of citizens is the top responsibility of the judicial power. All agencies, organizations and individuals have the obligation to respect, preserve and protect the rule of law and justice in court decisions. Supervision of judicial activities of the procuracies, appellate courts, cassation and reopening courts - are forms of state power control within the judicial apparatus to ensure independent judicial rights and only obey the law.

\section{Mechanisms for controlling state power}

State power control mechanism is a set of regulations and laws made by powerful actors to ensure that power is used for the right purposes and effectively. Three main mechanisms can be mentioned in the current state power control: Self-control of the rulers; the control between agencies in the state apparatus; social control.

First, the self-control of the ruler is the self-control mechanism of the holders of state power. The effectiveness of this mechanism depends on a number of factors, such as the cultural background of the ruler (individual understanding and enforcement of social norms and values); 
the ruler's level of awareness of conscience, responsibility, etc. However, this self-control is always fraught with risks and underappreciation, although in reality it may be possible for individuals to overcome the temptation to wield state power. This is hardly possible, both in theory and in practice, because "if you are limited by yourself, you are not limited". In fact, when there is too much power in hand, even good people can abuse power.

Second, the control between agencies in the state apparatus is a mechanism to control state power through the institutional system to prevent arbitrary, or subjective actions of the ruler rights, forcing them to make decisions in accordance with the established institutional system, in compliance with the provisions of the law. To ensure that state power cannot be abused or misused, Western countries have applied the theory of "separation of powers". Accordingly, different state agencies will be given different powers to create a mechanism to control power between the legislative, executive and judicial branches. However, in practice, there are differences in the application of this theory as well as differences in its effectiveness in each country. That depends on the historical circumstances, political culture and especially the awakening of the "elite" in each of those countries. For example, the British-style parliamentary system adopts a fairly flexible decentralized model; the US-style presidential republic adopts a "tough" decentralized model; French semi-presidential republic adopts a "mixed" decentralized model. Regardless of the model designed, the main idea of such institutions is based on the principle: Use power to control power, use coercive power to control other coercive power, making people hold public power, even though selfish or self-interested, cannot abuse power.

Third, social control is a mechanism for controlling state power from the social side. The actors involved in this process may include political parties, the Fatherland Front, social organizations (professional associations), the press and the people, etc.

\section{Methodology of Research}

In this paper, the authors use many kinds of researching methodologies to analysis international and national legal policy as well as law and regulations related to the check and balance of state power in managing land in Vietnam. Besides, the author base on the hypotheses developed in the study show how to use law and regulation to laws when implementing activities of the check and balance of state power in managing land in Vietnam. To examine these relationships, the author developed some hypotheses and tested these hypotheses using some empirical models. The developed models confirm the assumptions and demonstrate legal mechanism of the check and balance of state power in managing land in Vietnam. Moreover, statistic and survey are also used to finish this research. The author used the poll to survey the Vietnamese citizens, enterprises and associations in Vietnam. The author also sent the questionnaires to ask them some question related to the check and balance of state power in managing land in Vietnam. The author combined all of methodologies above to do this research. However, because of time and finance limitation, the working-paper cannot cover inclusive aspects of issues related to the topic. Thus, the author looks forward to taking the comments and opinions of readers and reviewer to do better in future.

\section{Findings and Discussion}


In the Vietnamese legal system, the provisions on land acquisition are one of the important provisions in the Land Law, consistent with the provisions of the 2013 Constitution. Therefore, innovations related to this issue have received great attention from the masses. To meet the requirements of reality, the Land Law has provisions on land recovery as follows:

(i) Specifying cases in which the State recovers land for national defense and security purposes (for example, a place to station an army, an office for work; construction of a military base, or a national defense structure, battlefields, special works on defense - security; construction of military stations and ports, etc.). Strictly control and narrow down the cases in which the State recovers land for socio-economic development for national and public interests. Accordingly, the State only recovers land when implementing projects of national importance for which investment policies are decided by the National Assembly; projects approved by the Prime Minister, investment decisions and projects approved by the People's Councils of provinces;

(ii) Amendment of the authority to recover land for administrative reform when implementing projects in the direction of the People's Committee of the province to decide on land recovery in case the recovered land includes both organizations and households, individuals are using the land;

(iii) To specify the order and procedures for land recovery for the purposes of national defense - security, socio-economic development for the public interests; principles, conditions, order and procedures for enforcement of the decision on compulsory inventory and enforcement of the decision on land recovery in order to create conditions for localities to implement uniformly;

(iv) Regulations in the direction of increasing the direct participation of the people, the responsibility for dialogue and accountability of the competent state agencies when people have not yet reached a consensus on land acquisition and compensation resettlement assistance.

The 2013 Land Law of Vietnam is the first law document detailing the order and procedures for land recovery, specifically the following basic steps:

(i) Making and approving plans for land acquisition, investigation, survey, measurement; Notice of land acquisition; Implement a damage assessment process.

(ii) Preparation and appraisal of compensation, support and resettlement plans.

(iii) Decision on land acquisition and approval of compensation, support and resettlement plan; Payment of compensation, support and land handover.

(iv) Coercive implementation of the decision on land acquisition.

The above are the progressive points of the 2013 Land Law. However, there are still shortcomings and limitations in the order and procedures for land acquisition, compensation, and resettlement support that need to be reviewed and completed as follows:

Firstly, the order and procedures for land recovery are prescribed in many documents including Laws, Decrees, Circulars and Decisions of the Provincial People's Committee. Currently, the regulations on the order and procedures for land recovery are scattered in many specific legal documents specified in Articles 67, 69, 70, 71, 93 of the 2013 Land Law; Article 17 Decree No. 43/2014/ND-CP, Article 28 and Article 30 Decree No. 47/2014/ND-CP; Article 13 of Circular No. 
37/2014/TT-BTNMT, so it is not easy for enforcers and people to fully systemize and properly understand the process of land acquisition.

Second, legal documents are not uniform, difficult to implement, and easy to cause controversy. The content of the notice of land recovery is regulated: "The content of the notice of land recovery includes the plan for land recovery, investigation, survey, measurement and tally". Clause 1, Article 17 of Decree No. 43/2014/ND-CP stipulating the plan for land acquisition, investigation, survey, measurement and tally, including the following contents: "(a) Reasons for land acquisition; (b) Area and location of the land to be acquired on the basis of existing cadastral records or detailed construction planning approved by competent state agencies; in case of land recovery according to the project implementation schedule, clearly state the land recovery schedule; (c) Plan of investigation, survey, measurement and tally; (d) Proposed relocation plan and resettlement arrangement; (d) Assign the task of formulating and implementing compensation, support and resettlement plans. However, in Clause 2, Article 17 of Decree No. 43/2014/ND-CP, the contents of the notice of land recovery include the contents at points (a), (b), (c), (d) of Clause 1. Article 17 of Decree 43/2014/ND-CP, excluding the content specified at point (dd) clause 1 of this article, so if understood according to the provisions of the 2013 Land Law, the notice of land recovery must be all 5 contents are specified in Clause 1, Article 17 of Decree 43/2014/ND-CP, but Clause 2, Article 17 of Decree 43/2014/ND-CP stipulates that the notice of land recovery includes only 4 contents.

Third, regulations on Compensation, Support and Resettlement Council are not specific and difficult to implement. Article 68 of the 2013 Land Law stipulates that the organization in charge of site clearance compensation includes the Compensation, Support and Resettlement Council and the Land Fund Development Organization. However, the Law and its guiding documents do not specify the composition of the members of the Compensation, support and resettlement Council, not specifying the tasks and powers of the Council and the mechanism of coordination of the Council with other agencies and organizations in the process of site clearance. In current practice, the Compensation, Support and Resettlement Council is established according to the provisions of Decree 47/2014/ND-CP.

Accordingly, "The chairperson of the district-level People's Committee is responsible for establishing the Compensation, Support and Resettlement Council to prepare compensation, support and resettlement plans and training and job change plans. For localities that have established land development fund organizations, the competent People's Committees may assign the task of formulating compensation, support and resettlement plans; training and career change plans for land development fund organizations". The decision to establish the Compensation and Resettlement Assistance Council must specify the principles of operation, coordination mechanism and responsibilities of each Council member. Thus, although the Provincial People's Committee has issued guiding documents, it is still general and there is no consensus. This affects the legal status and operation of the compensation council, while this is the subject of very important in the land acquisition process. 


\section{7 | International Journal of Scientific and Management Research 4(5) 141-150}

Fourthly, the order and procedures for land recovery do not prescribe the method of recording the current status of the acquired land at the time of land recovery notice. According to the provisions of Clause 2, Article 93 of the 2013 Land Law, properties attached to land that are created after receiving a notice of land recovery from a competent state agency are not entitled to compensation, so the recording of the current status the land acquired at the time of land acquisition notice has a very important meaning in the compensation of assets attached to the land. In practice, there are many cases where there is an incongruous dispute over assets attached to the land between the users of the recovered land and the compensation and clearance council, especially crops and other properties that are not the creation does not need to be declared. The reason is that the people who are using the recovered land intentionally create assets in anticipation of compensation for the purpose of increasing the value of land and assets on land when the land is recovered by the state. On the other hand, this is also a loophole for those in positions of authority and authority in the compensation and clearance council to increase the quantity of plants and animals, creating conditions for users of the acquired land to build assets associated with the land associated with the acquired land.

Fifth, the enforcement of the decision on compulsory inventory has not been strictly regulated and lacked specificity. To ensure that the compensation and support are accurate, fast and fair, the counting is an extremely important step. The accuracy, honesty and speed of the tally is a prerequisite for building a satisfactory compensation and support plan. Article 70 of the 2013 Land Law provides for the enforcement of the decision on compulsory inventory for land users who do not cooperate with the compensation and clearance council to conduct the tally. However, apart from this regulation, there is no document guiding the implementation while the enforcement of the decision on compulsory inventory is no less complicated than the enforcement of land acquisition. Clause 3, Article 70 stipulates that "The chairperson of the district-level People's Committee shall issue a decision on enforcement of the decision on compulsory inventory and organize the implementation of the decision on enforcement". Thus, the subject of implementation of the decision on enforcement of compulsory inventory has not been clearly defined in the law. Circular number 30/2014/TT-BTNMT dated June 2, 2014 of the Ministry of Natural Resources and Environment also does not clearly identify who is the subject of the decision to enforce the decision on tally. Meanwhile, for the enforcement of the decision on land recovery, a Committee for enforcement must be established according to the specified composition. Regarding the order and procedures for implementation of the Decision on enforcement of compulsory inventory prescribed in Clause 4, Article 70 of the 2013 Land Law, it is also not specific and strict, only stipulating that the organization assigned to carry out the enforcement has mobilized and persuaded if they persuade or hold dialogues with the coerced person but they do not comply, the enforcement decision shall be executed without specifying how long after having mobilized, persuaded, and held dialogues for the coerced person to voluntarily execute. The process at the enforcement meeting how to implement the tally decision, the enforcement plan, the duties of the members participating in the enforcement, the enforcement minutes, and many other issues have not been specified leading to a situation in each different project, the organization of enforcement of 
compulsory tally is different. In particular, there are projects that the organization assigned to carry out the compulsory tally is inexperienced, so when conducting compulsory tally did not have enough participants, people with assets were not invited to participate in the tally. Therefore, it is not possible to detect and fully reflect the actual status of assets attached to the land, especially the land areas with many graves, but when counting, because there is no land user participating in the tally. It is not known to records lead to inaccurate counting results, making it difficult to develop compensation and support plans.

Sixth, rules about collecting opinions in the process of making compensation, support and resettlement plans is unclear and difficult to implement. The organization in charge of compensation and ground clearance shall make plans for compensation, support and resettlement and coordinate with the commune-level People's Committees of the localities where the recovered land is located in collecting opinions on the plans. compensation, support and resettlement in the form of holding direct meetings with people in the area where land is recovered, and at the same time publicly posting plans for compensation, support and resettlement at the headquarters of the commune-level people Committee, common living places of the residential areas where the recovered land is located. Here, it is necessary to determine that the person whose land is acquired and needs to be consulted, so who the remaining subjects are has not yet been specified. Is the subject of consultation required to be a person living in the area where the land is acquired? Are tenants of business premises, employees working in businesses in the area subject to land expropriation? This regulation is not very clear, there are many different interpretations. This will lead to inconsistency in determining the object of consultation, affecting the legitimate interests of the people. Therefore, it is necessary to clearly define who are the people in the area with the acquired land to be consulted or specify the principles to determine.

Seventh, inadequacies in regulations on enforcement of land recovery decisions. The new points in the regulations on the composition of the enforcement committee and the specific conditions for conducting enforcement partly solve the practical difficulties. However, some issues in enforcement work are still not specific, creating confusion and inconsistency in implementation. The coercion plan prepared by the Coercive Implementation Board does not detail the necessary contents; while this option plays a decisive role and has a great influence on the results of the enforcement work. Therefore, the author thinks that it is necessary to consider supplementing the provisions on the basic contents of the coercive plan. This will ensure consistency and coherence in the enforcement of land acquisition decisions.

\section{Current status of land acquisition in Vietnam}

In recent years, along with the strong socio-economic development, the demand for urban embellishment, construction of local technical infrastructure, construction of works serving the common activities of the community has increased. To settle down, build new urban areas to serve the increasing housing and daily-life needs, in order for these projects to be implemented, the state needs to recover land. That will affect a part of people who are using land. In reality, many socioeconomic development projects have been delayed due to difficulties in compensation and site 
clearance, and people are not adequately compensated leading to protracted lawsuits, some bad molecules inciting people to protest, hindering the implementation of projects, causing social disorder and safety. Acquiring land for economic development for national and public benefits is one of the major solutions to create impetus for socio-economic development through projects to build industrial parks, processing export zones, high-tech zones, economic zones; projects to build new urban areas, rural residential areas, industrial clusters, etc. Cases of land acquisition for economic development purposes are regulated by the 2003 Land Law. These regulations are an important legal basis for the legal improvement process in accordance with the market economic management mechanism, the organization of land recovery, compensation, support and resettlement by the State in order to create a fund of "clean land" for investment projects, as well as encouraging investors to create a land fund through self-negotiation with the person whose land is recovered has better and better ensured the legitimate interests of the person whose land is recovered. However, the process of land acquisition for economic development has so far revealed many limitations and obstacles, such as many businesses without financial capacity, taking advantage of this regulation to "run projects", "holding land", giving rise to "hanging projects" in many places, wasting land resources.

\section{Conclusion}

In conclusion, it is necessary to perfect the legal provisions on land, including the law on land recovery to ensure the purpose of socio-economic development. In the practice of resolving administrative cases where people sue to request cancellation of land acquisition decisions, it shows that the order and procedures for land recovery are a core issue affecting the progress and success of land acquisition, site clearance work. The causes leading to people's disagreement with the decision of the state agency on land acquisition are many, including the incorrect application of the law by the state agency or the lack of understanding of the law. People's laws should make inappropriate demands.

\section{Acknowledgement}

This paper is made within the framework of the ministerial-level project "Controlling power in land acquisition in Vietnam today". Project leader: Doan Hong Nhung 2021-2022.

\section{References}

1) National Assembly (2013). Constitution

2) National Assembly of Vietnam (2013). Law of the land.

3) Government of Vietnam (2014). Decree No. 43/2014/ND-CP guiding the implementation of the land law

4) Government of Vietnam (2014). Decree No. 47/2014/ND-CP guiding the implementation of the land law 
5) Vietnam Ministry of Natural Resources and Environment, (2014). Circular No. 23/2014/TT-BTNMT dated May 19, 2014 providing for certificates of using-land rights, ownership of houses and other assets attached to land.

6) Vietnam Ministry of Natural Resources and Environment (2014). Circular No. 09/2021/TT-BTNMT dated June 30, 2021 on amendments and supplements to a number of articles of circulars detailing and guiding enforce the law of the land.

7) Documents of the 11th National Congress of Deputies, 2011. National Politics Publish House.

8) Montesquieu, (1748). Legal spirit. Da Nang Publishing House, 2010. p.46-50, p.230231

9) Andrew Le Sueur, Maurice Sunkin, Jo Eric, Khushal Murkens (2019). Separating and Balancing Powers. DOI: 10.1093/he/9780198820284.003.000. In book: Public Law

10) Inadequacies in the law provisions on order and procedures for land recovery for national defense and security purposes; socio-economic development for national and public interest, http://vkskh.gov.vn/nhung-bat-cap-trong-quy-dinh-cua-phap-luat-vetrinh-tu-thu-tuc-thu-hoi-dat-vi-muc-dich-quoc-phong-an_1784_381_2_a.html accessed 03/07/2021

11) Some recommendations on regulations on land recovery due to violations of land law, https://lsvn.vn/mot-so-kien-nghi-ve-cac-quy-dinh-thu-hoi-dat-do-vi-pham-phap-luatve-dat-dai.html , accessed 03/07/2021

12) Prof, Dr. Tran Ngoc Duong - Office of the National Assembly (2020), Controlling state power in building a socialist rule of law State of Vietnam

13) Assoc. Prof., Dr. Luu Van Quang (2020), Discussing the current state power control mechanism in Vietnam, Communist Review.

14) Luu Van Sung: Types of contemporary political institutions and reference values for Vietnam today, (2016). Publishing House of National Politics Truth, Hanoi, Vietnam.

15) Nhi Le, Perfecting the mechanism for controlling political power in the current Vietnamese political system, https://moha.gov.vn/danh-muc/hoan-thien-co-che-kiemsoat-quyen-luc-chinh-tri-trong-he-thong-chinh-tri-viet-nam-hien-nay-40950.html accessed September 9, 2020.

\section{Works Cited}

[1] Pham Thanh Nga \& Doan Hong Nhung, "Check and Balance Power in Land Acquisition: A Case Study of Vietnam," International Journal of Scientific and Management Research, vol. 04, no. 05, pp. 141-150, 2021. 